Abstracta Iranica Abstracta Iranica

Revue bibliographique pour le domaine irano-aryen

Volume 42-43 | 2021

Comptes rendus des publications de 2019-2020

\title{
Yousef Moradi, Almut Hintze. "A New Sealing of Pērōz from Takt-e Solaymān and Its Historical Context"
}

\section{Khodadad Rezakhani}

\section{(2) OpenEdition Journals}

Electronic version

URL: https://journals.openedition.org/abstractairanica/53138

DOI: 10.4000/abstractairanica.53138

ISSN: 1961-960X

Publisher:

CNRS (UMR 7528 Mondes iraniens et indiens), Éditions de l'IFRI

\section{Electronic reference}

Khodadad Rezakhani, "Yousef Moradi, Almut Hintze. "A New Sealing of Pērōz from Takt-e Solaymān and Its Historical Context"', Abstracta Iranica [Online], Volume 42-43 | 2021, document 6, Online since 30 December 2021, connection on 14 December 2022. URL: http://journals.openedition.org/ abstractairanica/53138; DOI: https://doi.org/10.4000/abstractairanica.53138

This text was automatically generated on 14 December 2022.

All rights reserved 


\title{
Yousef Moradi, Almut Hintze. “A New Sealing of Pērōz from Takt-e Solaymān and Its Historical Context"
}

\author{
Khodadad Rezakhani
}

\section{REFERENCES}

Yousef Moradi, Almut Hintze. "A New Sealing of Pērōz from Takt-e Solaymān and Its Historical Context" in Rika Gyselen (éd.). Persia (552 BCE - 758 CE): Primary Sources, Old and New. Res Orientales XXVIII. Bures-sur-Yvette: Groupe pour l'Étude de la Civilisations du Moyen-Orient, 2020, p.113-136.

1 This article, focusing on the fragment (ca. a quarter) of a remaining seal impression from Takht-e Solaymān, proposes to reconstruct the material, historical, and ritual context of the seal from which it originated. By comparing the seal's inscription with other known royal sealings, the authors propose the seal to belong to Pērōz (459-484) and proceed to reconstruct the missing part of the sealing, its iconography, and its inscription. Further constructing a context from the iconography, the authors put the sealing in a Zoroastrian ritual setting and connect it to the imagery of Ahura Mazda and the institutions of gift-giving and pilgrimage. It is, however, not specified why the sealing is attributed to Pērōz, while the crown of the horseman - a significant way of recognising a Sasanian king of kings - is missing the characteristic double wings of Pērōz's crown and is in fact much closer to the image on the coins of Pērōz's father Yazdgerd II or that of his brother, Walaxš. 


\section{AUTHORS}

\section{KHODADAD REZAKHANI}

Leiden University 